Historia Slavorum Occidentis

2021, nr $3(30)$

ISSN 2084-1213

DOI: $10.15804 /$ hso210301

\author{
Józef Dobosz (Poznań)
}

ORCID: 0000-0002-8222-0650

\title{
Gerard Labuda - szkic do portretu uczonego*
}

Słowa kluczowe: Gerard Labuda (1916-2010), mediewistyka, historia historiografii Keywords: Gerard Labuda (1916-2010), medieval studies, history of historiography

\begin{abstract}
One of the most outstanding Polish historians, Gerard Labuda (1916-2010) was connected with the University of Adam Mickiewicz in Poznan and the Polish Academy of Sciences for many years. The article presents his scholarly profile and provides an overview of the fields of his research and activities for science.
\end{abstract}

Gerard Labuda urodził się w Nowej Hucie (ściślej w Kamiennej Górze) w ówczesnym powiecie Kartuzy 28 XII 1916 r., jego ojcem był Stanisław Labuda, a matką Anastazja z Baranowskich. Uczęszczał do szkoły powszechnej w Luzinie, a od 1927 r. do gimnazjum klasycznego im. Jana Sobieskiego w Wejherowie ${ }^{1}$. Po jego ukończeniu w $1936 \mathrm{r}$. rozpoczął studia historyczne na Uniwersytecie Poznańskim i od tego czasu na stałe związał się z Poznaniem i tutejszym środowiskiem naukowym. Mówił o sobie zawsze, że jest Kaszubą w Poznaniu². Doświadczenia jako historyk nabierał pod okiem prof.

Spuścizna profesora Gerarda Labudy (zarówno materiały archiwalne, jak i biblioteka) znajduje się w Muzeum Piśmiennictwa i Muzyki Kaszubsko-Pomorskiej w Wejherowie, gdzie powstała Pracownia ds. opracowywania zbiorów bibliotecznych prof. Gerarda Labudy - zob. T. Fopke, Spuścizna Gerarda Labudy w muzeum wejherowskim. Budowa ksiażnicy i obchody Roku Gerarda Labudy - kalendarium dokonań, Acta Cassubiana 19 (2017), s. 106-126.

1 Na temat najwcześniejszych lat życia zob. Gerard Labuda, Życiorys [z 1955 r.], Teczka: Gerard Labuda W. Historyczny, Archiwum UAM, sygn. 789/16, k. 32-33.

2 Zob. wywiad: G. Labuda, „Jestem Kaszuba w Poznaniu”. Rozmowa z Beata Maciejewska, Gazeta Dolnośląska, dodatek do Gazety Wyborczej, 15.09.1999 (przedruk - G. Labuda, Zapiski 
Kazimierza Tymienieckiego i prof. Józefa Widajewicza, a zwłaszcza docenta Leona Bogusława Koczego, których uważał za swych mistrzów. Pewną rolę w uformowaniu jego zainteresowań odegrał też prof. Zygmunt Wojciechowski. Pierwsze publikacje przygotował i wydał jeszcze przed wojną (1935-1937). W 1939 r. otrzymał stypendium zagraniczne i przebywał do lipca tego roku na uniwersytecie w Lund (Szwecja). W 1942 r. uzyskał magisterium, a rok później doktoryzował się na Tajnym Uniwersytecie Ziem Zachodnich, w którego kieleckiej filii został wykładowcą w roku 1944. Na podstawie rozprawy Studia nad początkami państwa polskiego w $1946 \mathrm{r}$. habilitowal się na Wydziale Humanistycznym Uniwersytetu Poznańskiego i objął stanowisko zastępcy profesora oraz Katedrę Historii Słowiańszczyzny. W 1950 r. uzyskał profesurę nadzwyczajną, a w 1956 r. zwyczajną. Szybka i owocna kariera naukowa była w tym przypadku połączona z rozległą działalnością organizacyjną, którą realizował profesor G. Labuda nie tylko na Uniwersytecie Poznańskim, ale także w ramach Polskiej Akademii Umiejętności, potem Polskiej Akademii Nauk, jak też Poznańskiego Towarzystwa Przyjaciół Nauk i Instytutu Zachodniego ${ }^{3}$.

kaszubskie, pomorskie i morskie, Gdańsk 2000, s. 485 n.). Por. J. Borzyszkowski, Gerard Labuda - Kaszuba z Poznania. Droga od "Historii Pomorza” do „Historii Kaszubów”, Przegląd Zachodni 2006, nr 1, s. 61-82; C. Obracht-Prądzyński, Gerard Labuda - z Kaszub do historii Kaszubów, Nauka 2016, nr 3, s. 181-183.

3 Nie miejsce tutaj na szersze przedstawienie imponującej biografii Profesora, tymczasem odsyłam do już opublikowanych prac, przyczynków i wspomnień. Warto przede wszystkim zwrócić uwagę na Pro memoria Gerard Labuda (1916-2010), oprac. i wstęp J. Borzyszkowski, Gdańsk-Wejherowo 2011 (tu szczególnie cz. I: O życiu i dziełach Gerarda Labudy, s. 13-84, oraz cz. IV: Rodzina - Wielopolskich z Chrobrza i Labudów z Poznania, s. 297-380); G. Kasprzyk, M. Krośnicka, Gerard Labuda. Żeglarz na oceanie nauki, Luzino 2011; przyczynki do biografii pióra T. Schramma - Gerard Labuda. Zarys biografii, [w: ] Naukowe dzieto Profesora Gerarda Labudy, red. J. Dobosz, Poznań 2006, s. 9-19 (powtórzony w Pro memoria, s. 15-28); tegoż, Gerard Labuda 1 IX 1962 - 31 VIII 1965, [w:] Poczet Rektorów Almae Matris Posnaniensis, Poznań 2004, s. 199-208; M. Kosman, Gerard Labuda - człowiek i dzieło w 90. rocznice urodzin, Przegląd Zachodni 2006, nr 1, s. 31-59, a także okolicznościowe i wspomnieniowe artykuły: J. Strzelczyk, Gerard Labuda 1916-2010, Roczn. Hist. 76 (2010), s. 9-26; T. Jasiński, Gerard Labuda (28 XII 1916 - 1 X 2010), Kwart. Hist. 118 (2011), nr 2, s. 373-383; M. Kosman - Pożegnanie Profesora Gerarda Labudy (1916-2010), Zap. Hist. 75 (2010), z. 4, s. 157-163 oraz J. Dobosz, Profesor Gerard Labuda (1916-2010), Wiadomości Historyczne 2011, nr 1, s. 51-53; tegoż, Profesor Gerard Labuda (28 grudnia 1916 - 1 października 2010), Lituano-Slavica Posnaniensia. Studia Historica 14 (2013), s. 31-35. Trzeba też w tym miejscu odnotować ważny, wspomnieniowy artykuł J. Borzyszkowskiego - Wspomnienie o Wielkim Mistrzu... Profesorze Gerardzie Labudzie, [w:] tegoż, Moi Mistrzowie i Przyjaciele, Gdańsk 2015, s. 79-110. Zob. także ostatnio: J. Strzelczyk, Żywot niezwykty. W pięciolecie śmierci profesora Gerarda Labudy, PAUza Akademicka. Tygodnik Polskiej Akademii Umiejętności 8 (2015), 
Dorobek naukowy G. Labudy wymyka się spod kontroli zarówno co do liczebności publikacji, jak i rozległości horyzontów badawczych. Podczas wielu lat pracy twórczej opublikował on około 2000 rozmaitych prac (kilkadziesiąt książek, setki artykułów, edycje źródeł, recenzje i polemiki, ogromna działalność redakcyjna oraz sprawozdania). Różnorodne aspekty owej twórczości próbowano w ostatnich latach podsumować, a całość dokonań zestawić w bibliografię ${ }^{4}$. Gdy spoglądamy na jego naukowe dzieło, podziw wzbudza nie tylko wspomniana wyżej liczba i różnorodna tematyka publikacji, zarówno w języku polskim, jak i w językach kongresowych, ale przede wszystkim perfekcyjny warsztat i finezja analityczna. Podkreślić trzeba szczególnie rozległy zakres jego zainteresowań badawczych - uprawiał nie tylko szeroko pojętą mediewistykę (m.in. dzieje średniowieczne Polski i powszechne, dzieje wczesnej Słowiańszczyzny i Niemiec, historię Kościoła polskiego, dzieje Zakonu Krzyżackiego, czy też źródłoznawstwo i nauki pomocnicze historii), lecz także przecierał szlaki teoretycznej myśli źródłoznawczej w powojennej Polsce. Podejmował tematy przekrojowe (analityczno-syntetyczne), zajmował się historią historiografii (w tym na gruncie niemcoznawczym) oraz badaniem rozwoju metod historiograficznych na przestrzeni dziejów, a także historią regionalną (szczególnie wypracowanie koncepcji „Wielkiego Pomorza”), a nie stronił też od popularyzacji historii czy podejmowania tematyki szeroko rozumianych dziejów nauki (zwłaszcza polskiej). Trudno znaleźć w historiografii obszar, po którym G. Labuda nie poruszałby się swobodnie, każda właściwie z książkowych publikacji oraz większych rozpraw stanowiła, jeśli

nr 315 z 19 listopada, s. 1-3; J. Dobosz, Labuda Gerard, [w:] Luminarze nauki Uniwersytetu Poznańskiego w latach 1919-2019, red. Z. Pilarczyk, Poznań 2019, s. 352-360; H. Olszewski, Gerard Labuda, [w:] tegoż, Ludzie Uniwersytetu w mojej pamięci, Poznań 2015, s. 243-248. O profesorze Labudzie zob. też Profesor Gerard Labuda. Dokonania, idee, inspiracje, Acta Cassubiana 19 (2017), s. 7-126 (tu artykuły będące pokłosiem konferencji w Wejherowie z 2016 r.: Dariusza Andrzeja Sikorskiego, Jerzego Strzelczyka, Józefa Dobosza, Daniela Kalinowskiego, Józefa Borzyszkowskiego, Cezarego Obracht-Prądzyńskiego i Tomasza Fopke). Drukiem ukazały się też liczne inne wspomnienia i pierwsze próby oceny dorobku G. Labudy, wylicza je J. Strzelczyk (Gerard Labuda, s. 9, przyp. 2).

4 Najpełniej dotąd całokształt jego naukowego dorobku podsumowuje praca zbiorowa $\mathrm{Na}$ ukowe dzieto Profesora Gerarda Labudy, s. 9-159, będąca pokłosiem konferencji z grudnia 2006 r. Ciągle niekompletną i uzupełnianą bibliografię prac profesora Gerarda Labudy publikowano kilkakrotnie, ostatnie takie zestawienie pochodzi z 2006 r., a zarejestrowano w nim 1875 pozycji (Bibliografia prac Profesora Gerarda Labudy za lata 1935-2006, oprac. J. Strzelczyk, B. Wachowiak, J. Dobosz, H. Krzyżostaniak, [w:] Naukowe dzieto Profesora Gerarda Labudy, s. 161-282). Istotne uzupełnienia oraz kontynuację za ostatnich kilka lat (w sumie 38 pozycji) zestawił Jerzy Strzelczyk - tegoż, Gerard Labuda 1916-2010, s. 24-26. 
nie przełom w polskiej nauce historycznej, to istotne wydarzenie, które zmuszało do dyskusji i stawiania kolejnych pytań oraz problemów badawczych.

Efekty wieloletnich dociekań naukowych uczonego zbiera kilka retrospektyw jego prac, opatrzonych często obszernymi odautorskimi komentarzami - Studia nad poczatkami państwa polskiego ${ }^{5}$; Polsko-niemieckie rozmowy o przeszłości ${ }^{6}$ oraz Szkice historyczne X-XI wieku. Z dziejów organizacji Kościoła w Polsce we wczesnym średniowieczu ${ }^{7}$, a także Studia krytyczne o poczatkach Zakonu Krzyżackiego w Prusach i na Pomorzu i Rozważania nad teoria i historia kultury i cywilizacji. Wybór studiów i rozpraw $^{9}$. Jedną z najważniejszych kwestii, jakie podejmował G. Labuda, była problematyka najdawniejszych dziejów monarchii piastowskiej (X-XI w.), a szczególnie jej narodzin i uformowania się polskiego Kościoła. Owe studia i rozprawy o początkach i rozwoju państwowości piastowskiej w X-XI stuleciu należą dzisiaj niewątpliwie do klasyki naszej historiografii i doczekały się już pierwszych prób podsumowania i analizy ${ }^{10}$. Sięgają one czasów studiów historycznych ich autora u schyłku okresu dwudziestolecia międzywojennego oraz trudnych lat okupacji. Otworzyła je obszerna

5 G. Labuda, Studia nad poczatkami państwa polskiego, t. 2, Poznań 1988, ss. 567 oraz tegoż, Studia nad początkami państwa polskiego, t. 3, Wodzisław Śląski 2012, ss. 586.

6 Tenże, Polsko niemieckie rozmowy o przeszłości. Zbiór rozpraw i artykutów, Poznań 1996, ss. 551.

7 Tenże, Szkice historyczne X-XI wieku. Z dziejów organizacji Kościoła w Polsce we wczesnym średniowieczu, Poznań 2004, ss. 487, tu również prace wcześniej niepublikowane.

8 Tenże, Studia krytyczne o początkach Zakonu Krzyżackiego w Prusach i na Pomorzu. Pisma wybrane, Poznań 2007, ss. 407 - w pierwotnym zamyśle miały to być studia wybrane traktujące o dziejach Pomorza, Kaszubów i Krzyżaków, ale zmianę spowodowało przygotowanie do druku I tomu Historii Kaszubów w dziejach Pomorza.

9 Tenże, Rozważania nad teoria i historia kultury i cywilizacji. Wybór studiów i rozpraw, Poznań 2008, ss. 561.

10 Zob. R. Michałowski, Poczatki państwa polskiego w badaniach naukowych Gerarda Labudy, [w:] Naukowe dzieło Profesora Gerarda Labudy, s. 71-86; J. Kłoczowski, Gerard Labuda - historyk wczesnego chrześcijaństwa polskiego, [w:] Naukowe dzieło Profesora Gerarda Labudy, s. 53-69, a także wydane ostatnio materiały z konferencji naukowej z grudnia 2010 r., zorganizowanej przez Polską Akademię Nauk Oddział w Poznaniu, Wydział Historyczny Uniwersytetu im. Adama Mickiewicza w Poznaniu oraz Polską Akademię Umiejętności - Początki państwa i Kościoła polskiego w badaniach naukowych Profesora Gerarda Labudy, Poznań 2011, ss. 70 (a tu teksty: Jerzego Strzelczyka o badaniach nad pierwszą monarchią piastowską, s. 9-18; Romana Michałowskiego o badaniach nad najstarszym Kościołem polskim, s. 19-38; Jerzego Wyrozumskiego o dociekaniach nad dziejami świętych Wojciecha i Stanisława, s. 39-51 oraz Józefa Dobosza o próbach popularyzacji najdawniejszych dziejów monarchii piastowskiej i Kościoła w Polsce, s. 53-70). 
rozprawa z 1938 r. poświęcona relacjom kościelnym Poznania i Magdeburga w drugiej połowie X w., na podstawie której na przełomie 1943 i 1944 r. złożył egzaminy doktorskie ${ }^{11}$. Ten nurt dociekań stał się potem, obok szeroko rozumianych badań slawistycznych, jednym z najważniejszych obszarów penetracji badawczych autora. W 1946 r. drukiem ukazała się rozprawa o początkach państwa polskiego ${ }^{12}$, w której G. Labuda zebrał swe poglądy w kwestii ukształtowania się piastowskiej monarchii. Następne lata przyniosły zaangażowanie G. Labudy w zespole badań początków państwowości polskiej, który wyrósł na kanwie zbliżającego się milenium państwa i Kościoła polskiego. W jego publikacjach coraz wyraźniej zaznaczał się nurt pomorzoznawczy, a także slawistyczny oraz źródłoznawczy, a w nich sporo miejsca zajmowały kwestie powiązane z formowaniem się państwa piastowskiego. Na czoło wysunęły się jednak dwa wielkie przedsięwzięcia - powołanie wespół z Aleksandrem Gieysztorem i Brygidą Kürbisówną „Studiów Źródłoznawczych” oraz redagowanie od schyłku lat pięćdziesiątych XX w. Stownika starożytności stowiańskich (w którym on sam opublikował wiele haseł odnoszących się do najdawniejszego okresu historii Polski). Na temat pierwszych dwóch wieków dziejów polskiej (polańskiej) państwowości powstało w tym czasie sporo prac drobniejszych. Za jedną z ważniejszych trzeba uznać artykuł o świętym Wojciechu z 1947 r. ${ }^{13}$, który otworzył, kontynuowane $\mathrm{z}$ dużą intensywnością zwłaszcza u schyłku XX w., badania G. Labudy nad tą ważną $\mathrm{w}$ dziejach Polski postacią. Istotne znaczenie miały: włączenie się do dyskusji na temat imienia pierwszej żony Mieszka ${ }^{14}$ czy też obszerna wypowiedź o nowym

11 G. Labuda, Magdeburg i Poznań (Założenie arcybiskupstwa magdeburskiego i biskupstwa poznańskiego na tle wschodniej polityki misyjnej Ottona Wielkiego), Roczn. Hist. 14 (1938), z. 2, s. 185-238. O fakcie złożenia doktoratu, a tylko nieco wcześniej magisterium, zob. Gerard Labuda, Życiorys [z 1955 r.], Teczka: Gerard Labuda W. Historyczny, Archiwum UAM, sygn. 789/16, k. 32; Gerard Labuda (dane biograficzne), Teczka: Gerard Labuda habilitacja, Archiwum UAM, sygn. 191/33 oraz tamże, Zaświadczenie [z 14 czerwca 1945 r. o uzyskaniu doktoratu].

12 Tenże, Studia nad początkami państwa polskiego, Poznań 1946, ss. VI, 353. Wznowienie tej rozprawy, opatrzone komentarzami autorskimi, ukazało się ponad czterdzieści lat później Studia nad początkami państwa polskiego, t. 1, Poznań 1987, ss. XVI+VI+523, edycja ta zawiera też wspomniany w przyp. 1 artykuł o Poznaniu i Magdeburgu (s. 355-410) oraz Komentarze (s. 411-522). Całość poprzedzona jest wprowadzeniem pióra Aleksandra Gieysztora - Zamiast przedmowy, s. V-XII.

13 G. Labuda, Św. Wojciech w literaturze i legendzie średniowiecznej, [w:] Święty Wojciech 997-1947, red. Z. Bernacki i in., Gniezno 1947, s. 89-112.

14 Tenże, Dąbrówka czy Dobraw(k)a? Uzupetnienie do dyskusji o poprawne imię żony Mieszka I, Slavia Occidentalis 18 (1939/1947), s. 126-138. 
wydaniu relacji Ibrahima ibn Jakuba ${ }^{15}$, podobnie jak podjęcie na nowo tematu dokumentu Dagome iudex ${ }^{16}$.

Niektóre powyższe rozprawy wyraźniej akcentowały kwestie, którymi uczony zajął się poważnie w latach pięćdziesiątych XX stulecia - chodzi o gruntowne studia źródłoznawcze, które łączył z dociekaniami nad początkami polskiej państwowości. Do analiz tekstu Ibrahima ibn Jakuba i studiów nad Dagome iudex dodał wkrótce projekt edycji najstarszych źródeł rozświetlających narodziny i pierwsze dziesięciolecia państwa piastowskiego ${ }^{17}$. W jakimś stopniu efektem tego opracowania była zapewne edycja tekstów źródłowych poświęconych najstarszej Słowiańszczyźnie ${ }^{18}$. Doświadczenia na tym polu spożytkował wiele lat później, przygotowując wspólnie z Benonem Miśkiewiczem powszechnie niegdyś używany w dydaktyce uniwersyteckiej wybór źródeł do historii Polski w wiekach średnich ${ }^{19}$. Nurt źródłoznawczy kontynuował również w następnych studiach, jak choćby w dużym artykule poświęconym wątkom polskim w Pieśni o Rolandzie ${ }^{20}$. Wkrótce swe dociekania nad tymi zagadnieniami ukoronował dwoma książkami, w których zajął się źródłami, legendami i opowieściami o wczesnym rodowodzie, ukazującymi najdawniejsze dzieje polskiej państwowości.

Pierwsza z nich to drobiazgowa analiza kilku tekstów powstałych za granicami piastowskiego władztwa czy szerzej Słowiańszczyzny ${ }^{21}$. Otwiera ją tekst odnoszący

15 Tenże, Ibrahim ibn Jakub. Najstarsza relacja o Polsce w nowym wydaniu, Roczn. Hist. 16 (1947), s. 100-183.

16 Tenże, Znaczenie prawno-polityczne dokumentu Dagome iudex”, Nasza Przeszłość 4 (1948), s. 33-60.

17 Tenże, Źródła objaśniające początki państwa polskiego. Projekt wydawnictwa, Kwart. Hist. 58 (1951), nr 1-2, s. 112-122.

18 Tenże, Stowiańszczyzna pierwotna. Wybór tekstów, Warszawa 1954, ss. 359 (seria: Materiały źródłowe do historii Polski epoki feudalnej, red. M. Małowist, [t.] 1). Po latach G. Labuda powrócił do tego ważnego wyboru tekstów źródłowych i przygotował jego nowe, gruntownie poprawione i uzupełnione wydanie pod zmienionym tytułem - Słowiańszczyzna starożytna i wczesnośredniowieczna. Antologia tekstów źródłowych, Poznań 1999, ss. 275.

19 Antologia ta ukazała się nakładem Uniwersytetu im. Adama Mickiewicza w Poznaniu w dwóch wydaniach. Początkowo autorzy opublikowali ją w czterech zeszytach pod wspólnym tytułem: Teksty źródłowe do ćwiczeń z historii Polski epoki feudalizmu (do połowy XIV wieku), oprac. G. Labuda, B. Miśkiewicz, z. 1-4, Poznań 1961-1963 (z. 1 zawierał teksty do najstarszych dziejów Polski na s. 31 n.). Drugie wydanie, z istotnymi zmianami w stosunku do pierwotnego projektu, zatytułowano: Wybór źródeł do historii Polski średniowiecznej (do połowy XV), t. 1-3, Poznań 1966-1970.

20 Tenże, Polska w pieśni o Rolandzie, Roczn. Hist. 22 (1955/56), s. 35-59.

21 Tenże, Źródła, sagi i legendy do najdawniejszych dziejów Polski, Warszawa 1960, ss. 346. 
się do okresu tuż przed pojawieniem się państwa polańskiego na dziejowej arenie, a poświęcony wyłuskaniu i poddaniu badaniom wszystkich wzmianek o ziemiach polskich w opisie Europy króla Alfreda Wielkiego. Następnie szczegółowemu oglądowi G. Labuda poddał Pieśń o Hunach oraz Herwararsaga w aspekcie walk stoczonych między Hunami i Gotami nad Wisłą. Podobnie podszedł do anglosaskiego poematu Widsidh. W dwóch kolejnych odsłonach swej książki autor powrócił do czasów bliższych uformowania państwa piastowskiego, zajmując się informacjami z Pieśni o Rolandzie, w których pojawia się Słowiańszczyzna i Polska, a następnie analizując opowieść o Walgierzu z Tyńca i Wisławie z Wiślicy jako polską wersję opowieści o Walterze i Helgundzie. Druga książka to w pewnym stopniu powtórzenie elementów pierwszej, ale tutaj uczony położył nacisk na komentowane edycje kilku kluczowych tekstów skandynawskich i anglosaskich do wczesnych dziejów Słowiańszczyzny ${ }^{22}$. Pierwszym jest wydanie Chorografii Orozjusza w anglosaskim tłumaczeniu Alfreda Wielkiego, następnym wspomniany wyżej Widsidh, a całość zamyka Herwararsaga. Bezpośrednio do początkowych lat państwowości polskiej odniósł się G. Labuda w kilku ważnych artykułach, m.in. przeprowadzając krytykę przekazu Kosmasa o utracie Krakowa przez Czechów, zamieszczonego w dziele czeskiego kronikarza pod rokiem $999^{23}$, czy szczegółowo spoglądając na utratę Moraw przez Piastów w XI stuleciu ${ }^{24}$. Dał też pełniejsze spojrzenie na kwestię suwerenności państwa polskiego w X-XII w. ${ }^{25}$ oraz relacje polsko-skandynawskie $\mathrm{w}$ dobie budowania podstaw terytorialnych i politycznych piastowskiego władztwa ${ }^{26}$. Przykładem dogłębnej analizy krótkiej wzmianki źródłowej

Państwowe Wydawnictwo Naukowe, wydawca książki, wznowiło ją już rok później. W latach 1961-1965 dzieło to doczekało się blisko 10 recenzji i omówień w językach: polskim, słowackim, czeskim i niemieckim.

22 Źródła skandynawskie i anglosaskie do dziejów Stowiańszczyzny, wyd. G. Labuda, Warszawa 1961, ss. 262.

23 G. Labuda, O rzekomej utracie Krakowa przez Czechów w roku 999, Slavia Occidentalis 20 (1960), z. 2, s. 79-93.

24 Tenże, Utrata Moraw przez państwo polskie w XI wieku, [w:] Studia z dziejów polskich i czechostowackich, red. E. i K. Maleczyńscy, t. 1, Wrocław 1960, s. 9-124.

25 Tenże, Zagadnienie suwerenności Polski wczesnofeudalnej w X-XII wieku, Kwart. Hist. 67 (1960), nr 4, s. 1035-1068.

26 Tenże, Polska a Skandynawia w IX-X wieku, [w:] Początki państwa polskiego. Księga tysiąclecia, t. 1, Poznań 1962, s. 299-317, tutaj też odnajdujemy dwa inne artykuly odnoszące się do interesującego nas zagadnienia - Wpływ powstania państwa polskiego na rozwój dziejowy Pomorza, s. 269-279 (t. 2) oraz Organizacje państwowe Stowian zachodnich w okresie ksztattowania się państwa polskiego od VI do połowy X wieku, s. 43-71 (t. 1). 
jest artykuł powstały na kanwie zapisu o biskupie o imieniu Daugerius z bulli gnieźnieńskiej z $1136 \mathrm{r}^{27}$, czasami identyfikowanym z Ungerem.

Osobne miejsce w dorobku naukowym G. Labudy zajmują zebrane w trzech tomach studia nad dziejami zachodniej Słowiańszczyzny ${ }^{28}$, w których pomieścił on sporo informacji o pierwszych dwóch wiekach dziejów monarchii piastowskiej, zwłaszcza w kontekście polskiej obecności nad Bałtykiem i relacji ze Skandynawią. Poprzedzały je drobniejsze prace z lat czterdziestych i pięćdziesiątych XX w. poświęcone szeroko pojętej Słowiańszczyźnie, a w jakiś sposób na ich kanwie wyrastała koncepcja przygotowania wielkiej zbiorowej syntezy dziejów Pomorza, zresztą realizowana konsekwentnie aż do początku XXI w. ${ }^{29}$ Również ze szczegółowych wcześniejszych studiów oraz recenzji i polemik z uczonymi niemieckimi rodziła się inna synteza, tym razem autorska, poświęcona dziejom naszej granicy zachodniej, a dedykowana trzem wielkim poznańskim uczonym - Józefowi Kostrzewskiemu, Kazimierzowi Tymienieckiemu i Zygmuntowi Wojciechowskiemu ${ }^{30}$. W pracy tej autor sporo uwagi poświęcił najdawniejszym dziejom państwa piastowskiego, wychodząc od uformowania się granicy między światem słowiańskim i germańskim, by przejść do warunków tworzenia organizacji państwowych w jej rejonie oraz genezy państwowości niemieckiej i polskiej, a następnie do ukształtowania się granicy od czasów pierwszych Piastów aż po panowanie Krzywoustego. Tę sekwencję książki zamka analiza szczegółowego przebiegu granicy polsko-niemieckiej.

W latach sześćdziesiątych XX w. poznański mediewista powrócił do analitycznych rozpraw odnoszących się do dziejów polskiego Kościoła w pierwszych wiekach jego działalności, nawiązując tym samym do swych starszych prac, bądź to przedwojennych, bądź to przedłożonych tuż po wojnie. Jednym z ważniejszych artykułów tego nurtu jego twórczości była analiza ukształtowania się organizacji diecezjalnej na Pomorzu i na Kujawach w stuleciach XI i XII ${ }^{31}$. Tutaj też trzeba zaliczyć odnowienie zainteresowania świętym Wojciechem i jego żywotami przez próbę rekonstrukcji drogi

\footnotetext{
27 Tenże, Daugerius episcopus, Onomastica 7 (1961), z. 1-2, s. 269-280.

28 Tenże, Fragmenty dziejów Słowiańszczyzny zachodniej, t. 1-3, Poznań 1960-1975, odpowiednio ss. $312,279,351$.

29 Zob. Bibliografia prac Profesora Gerarda Labudy.

30 G. Labuda, Polska granica zachodnia. Tysiąc lat dziejów politycznych, Poznań 1971, ss. 453, następne jej wydanie ukazało się w 1974 r. (ss. 472), a wokół niej zogniskowała się bogata dyskusja (w sumie kilkadziesiąt omówień, recenzji i polemik).

31 Tenże, Początki diecezjalnej organizacji kościelnej na Pomorzu i na Kujawach w XI i XII wieku, Zap. Hist. 33 (1968), z. 3, s. 19-60.
} 
biskupa praskiego do $\operatorname{Prus}^{32}$, a także podjęcie pierwszych istotniejszych studiów nad sprawą świętego Stanisława ${ }^{33}$.

W następnym okresie swej działalności naukowej G. Labuda podtrzymywał zainicjowane wcześniej wątki, a w tym i studia nad uformowaniem się i wczesnymi dziejami państwa piastowskiego. Ważne miejsce pośród nich zajmuje obszerne studium historiograficzne, w którym dokonuje on rozrachunku osiągnięć historyków z Polski i Niemiec na polu dociekań nad początkami państwowości polskiej33. Okazją do pełniejszej oceny czasów piastowskich była 300. rocznica wygaśnięcia dynastii, która przypadała w 1975 roku. Nie mogło zabraknąć tutaj głosu G. Labudy, który ukazał rolę Piastów jako twórców państwa polskiego ${ }^{35}$. Swoistym pokłosiem tych dwóch wypowiedzi była lżejsza w formie analiza stanowisk historyków na temat roli Piastów w procesie budowania polskiej państwowości ${ }^{36}$, natomiast podjęcie rozważań nad najstarszymi dziejami opactwa benedyktynów w Mogilnie to kontynuacja badań nad najwcześniejszymi polskimi instytucjami kościelnymi, przede wszystkim na gruncie szczegółowych analiz źródłowych ${ }^{37}$. W tym czasie w twórczości G. Labudy można dostrzec wyraźnie już rysujące się trzy nowe nurty - pierwszy, który przynajmniej częściowo nakładał się na interesujące nas kwestie formowania

32 Tenże, Droga biskupa praskiego Wojciecha do Prus, Zap. Hist. 34 (1969), z. 3, s. 9-28.

33 Tenże, List papieża Paschalisa II do niewiadomego arcybiskupa polskiego z początku XII $w$. Przyczynek do dyskusji nad faktum biskupa krakowskiego Stanisława, Śląski Kwartalnik Historyczny „Sobótka” 26 (1971), nr 4, s. 415-434 (zob. reedycję: List papieża Paschalisa II do arcybiskupa polskiego z poczatku XII wieku, [w:] G. Labuda, Szkice historyczne X i XI wieku. $Z$ dziejów organizacji Kościoła w Polsce we wczesnym średniowieczu, Poznań 2004, s. 31-450). Do tej kwestii będzie Gerard Labuda powracał wielokrotnie w swych pracach, uczestnicząc w ciągle właściwie niedokończonej polemice (zob. Bibliografia prac Profesora Gerarda Labudy).

34 Tenże, Początki państwa polskiego w historiografii polskiej i niemieckiej, [w:] Stosunki polsko-niemieckie w historiografii, cz. 1: Studia z dziejów historiografii polskiej i niemieckiej, red. J. Krasuski, G. Labuda, A.W. Walczak, Poznań 1974, s. 150-217.

35 Tenże, Piastowie twórcami państwa polskiego, [w:] Piastowie w dziejach Polski. Zbiór artykułów z okazji trzechsetnej rocznicy wygaśnięcia dynastii Piastów, red. R. Heck, Wrocław 1975, s. 10-48.

36 Tenże, Co historycy sądzą o Piastach jako twórcach państwa polskiego?, Kronika Wielkopolski 6 (1978), nr 1-4, s. 35-48.

37 Tenże, Początki klasztoru w świetle źródet pisanych, [w:] Materiały sprawozdawcze $z$ badań Zespotu Pobenedyktyńskiego w Mogilnie, red. K. Nowiński, z. 1, Warszawa 1978, s. 21-60. Tę obszerną i ważną rozprawę po latach autor gruntownie przepracował i opublikowal ponownie jako: Poczatki klasztoru Benedyktynów w Mogilnie, [w:] G. Labuda, Szkice historyczne X i XI wieku, s. 305-360. 
się i rozwoju państwa piastowskiego, odnosił się do przygotowania wielotomowej syntezy dziejów dyplomacji polskiej ${ }^{38}$, drugi prowadził ku coraz głębszym studiom nad dziejami Zakonu Krzyżackiego ${ }^{39}$, trzeci zaś, to Jan Długosz i jego spuścizna historiograficzna ${ }^{40}$. W tym też czasie dojrzewał zapoczątkowany jeszcze w latach sześćdziesiątych XX w. zamysł podjęcia gruntownej polemiki z głęboko zakorzenionymi w naszej świadomości i tradycji koncepcjami T. Wojciechowskiego, zwłaszcza w kwestii konfliktu biskupa Stanisława i króla Bolesława Śmiałego. Drukowanym wstępem do tego była publikacja poświęcona 75. rocznicy ukazania się Szkiców historycznych jedenastego wieku ${ }^{41}$. Większość tych niezwykle ciekawych i „bezkontaktowych" polemik od czasów konferencji poświęconej sprawie świętego Stanisława, która odbyła się z okazji 900. rocznicy śmierci biskupa krakowskiego, przez wiele lat zalegała w szufladzie. Dopiero lata dziewięćdziesiąte XX stulecia przyniosły stopniowe publikowanie kolejnych, jak się je czasami nazywa, „antyszkiców” G. Labudy.

W latach osiemdziesiątych XX w. w twórczości uczonego jeszcze wyraźniej zaznaczył się nurt badań nad dziejami najwcześniejszego polskiego Kościoła oraz jego strukturą. Rozważał on m.in. kwestie ewentualnej misji cyrylo-metodiańskiej na ziemiach polskich ${ }^{42}$, prowadził badania nad najstarszymi strukturami organizacyjnymi Kościoła ${ }^{43}$, zastanawiał się też nad wielokrotnie dyskutowanymi problemami

38 Pierwszy tom redagowanej przez Gerarda Labudę Historii dyplomacji polskiej ukazał się w 1980 r. - Historia dyplomacji polskiej (połowa X-XX w.), t. 1: Połowa X w. - 1572, red. M. Biskup, Warszawa 1980. Sam G. Labuda był autorem znaczącej części tego tomu - część I: Dyplomacja polska wczesnego feudalizmu (wiek X-1306 r.), s. 33-218. Zob. też Bibliografia prac Profesora Gerarda Labudy.

39 Najważniejsze rozprawy z tego zakresu zostały ostatnio zebrane w tomie Studia krytyczne o początkach Zakonu Krzyżackiego w Prusach i na Pomorzu. Pisma wybrane. Uwieńczeniem badań nad dziejami Zakonu Krzyżackiego była przygotowana wspólnie z Marianem Biskupem synteza: Dzieje Zakonu Krzyżackiego w Prusach. Gospodarka, społeczeństwo, państwo, ideologia, Gdańsk 1986, ss. 624 (wznowienie 1988).

40 Ukoronowaniem tego nurtu badawczego była publikacja szeroko dyskutowanej pracy źródłoznawczej o zaginionej kronice w Długoszowych Annales - Zaginiona kronika z pierwszej połowy XIII wieku w Rocznikach Królestwa Polskiego Jana Długosza. Próba rekonstrukcji, Poznań 1983, ss. 308.

41 G. Labuda, W 75 rocznicę ukazania się „Szkiców historycznych” Tadeusza Wojciechowskiego, Kwart. Hist. 88 (1981), nr 2, s. 323-351, por. przedruk tego artykułu: tenże, Szkice historyczne X-XI wieku, s. 15-46.

42 Tenże, Kraków biskupi przed 1000 r. Przyczynek do dyskusji nad dziejami misji metodiańskiej $w$ Polsce, Studia Historyczne 27 (1984), z. 3, s. 371-412.

43 Tenże, O najstarszej organizacji Kościoła w Polsce, Przegląd Powszechny 1984, nr 6, s. 373-396. 
- skąd przybyło do Polski chrześcijaństwo ${ }^{44}$ oraz drugiej metropolii w Polsce Bolesława Chrobrego ${ }^{45}$. Sporo jego mniejszych prac, odnoszących się do pierwszych wieków państwa Piastów, zostało wówczas poszerzonych oraz zebranych w jeden obszerny tom i wydanych jako kontynuacja Studiów nad poczatkami państwa polskie$\mathrm{go}^{46}$. Zapewne w związku z dociekaniami nad sprawą biskupa Stanisława pojawiło się też zainteresowanie losami jego adwersarza - króla Bolesława Śmiałego. Warto tutaj wspomnieć o pracy poświęconej relacjom tego władcy z sąsiadami (Czechami i Pomorzanami ${ }^{47}$ czy też ważnym tekście o królu Bolesławie, fundatorze biskupstw w Polsce ${ }^{48}$.Zaczęły też ukazywać się pierwsze drobne prace podejmujące rewizję konstrukcji T. Wojciechowskiego o dziejach schyłku Xi XI w., które dzięki popularności jego Szkiców historycznych utrwaliły się w polskiej historiografii. Ważne miejsce w tej ponadpokoleniowej polemice odgrywał klasztor tyniecki, którego początki G. Labuda usiłował przedstawić w nowym świetle ${ }^{49}$, podobnie jak źródłoznawcze dociekania nad żywotami świętego Stanisława ${ }^{50}$.

Schyłek lat osiemdziesiątych XX w. przyniósł próbę podsumowania dokonań polskiej historiografii nad dziejami wczesnego średniowiecza ${ }^{51}$, a także kontynu-

44 Tenże, Jakimi drogami przyszło do Polski chrześcijaństwo?, Nasza Przeszłość 69 (1988), s. 39-82, por. tenże, Szkice historyczne X-XI wieku, s. 101-138.

45 Tenże, Zagadka drugiej metropolii w Polsce za czasów Bolesława Chrobrego, Nasza Przeszłość 62 (1984), s. 7-25.

46 Tenże, Studia nad początkami państwa polskiego, t. 2. Autor w jedenastu częściach pomieścił cały ciąg zagadnień związanych państwem i Kościołem w dobie wczesnopiastowskiej, głównie odnoszących się do X-XI stulecia. Odnajdziemy tu kwestie związane z imiennictwem dynastii, obrządkiem słowiańskim, relacjami z sąsiadami oraz granicami piastowskiej monarchii, a także zagadnienia takie jak: Dagome iudex, Kraków jako siedziba biskupia i gród stołeczny, budowle sakralne Wawelu i Ostrowa Lednickiego oraz kwestie organizacji kościelnej i zagadkę drugiej metropolii z czasów Chrobrego.

47 Tenże, Zatargi z Czechami i Pomorzanami w pierwszym okresie rządów Bolesława Śmiałego (1058-1073), Zap. Hist. 50 (1985), z. 3, s. 33-50.

48 Tenże, Król Bolesław „qui constituit episcopatus per Poloniam”, Studia Źródłoznawcze 30 (1987), s. 51-57.

49 Pierwszą istotną publikacją był artyku1: $Z$ dyskusji nad początkami klasztoru benedyktyńskiego w Tyńcu. Fundatorzy i pierwsi opaci, [w:] Symbolae historiae artium. Studia z historii sztuki Lechowi Kalinowskiemu dedykowane, Warszawa 1986, s. 93-109.

50 Zob. np. tenże, Zapiski rocznikarskie w żywotach Świętego Stanisława Wincentego z Kielczy, Roczniki Humanistyczne 34 (1986), z. 2, s. 319-332.

51 Tenże, Polskie wczesne średniowiecze $w$ historiografii lat 1937-1987, Kwart. Hist. 94 (1987), nr 1, s. 23-65. 
ację badań nad dziejami Pomorza, ukierunkowaną na dzieje Kaszubów i Kaszubszczyzny $^{52}$. Przede wszystkim jednak na gruncie wielkich doświadczeń badawczych G. Labuda przedłożył wreszcie swe pierwsze dzieło popularnonaukowe, które dawało pełny obraz narodzin i najwcześniejszych dziesięcioleci funkcjonowania państwa Piastów ${ }^{53}$. Nie trzeba też było długo czekać na kolejną ważną, wręcz przełomową publikację naukową - tym razem obiektem zainteresowań uczonego stał się król Mieszko II, a celem autora było skruszenie „czarnej legendy” tego władcy jako króla gnuśnego ${ }^{54}$. W tym czasie można zaobserwować ponowny zwrot jego uwagi ku najdawniejszym dziejom Polski, a zwłaszcza świętemu Wojciechowi, zjazdowi gnieźnieńskiemu, wczesnemu Kościołowi i klasztorom oraz sprawie świętego Stanisława ${ }^{55}$. Zebranie tych i innych badań stanowi wydana w 1996 r. kontynuacja Pierwszego państwa polskiego, w której G. Labuda ukazał losy odbudowanej monarchii, balansującej między jednością i rozbiciem od panowania Kazimierza Odnowiciela aż po Bolesława Krzywoustego ${ }^{56}$.

Rok 2000 to zamknięcie dociekań uczonego nad dwoma polskimi świętymi Wojciechem i Stanisławem - w postaci monografii. Temu pierwszemu poświęcił on obszerną rozprawę z analizą - w świetle zachowanych przekazów źródłowych - jego życia, kultu i znaczenia dla trzech środkowoeuropejskich państw, czyli Polski, Czech i Węgier ${ }^{57}$. Książka o świętym Stanisławie była zakończeniem dyskursu z tezami T. Wojciechowskiego w odniesieniu do wydarzeń z lat 1078-1079 i ich

52 Liczne prace z tego zakresu zob. Bibliografia prac Profesora Gerarda Labudy. Szczególnym podsumowaniem wieloletnich dociekań była synteza średniowiecznych dziejów Kaszub - G. Labuda, Historia Kaszubów w dziejach Pomorza, t. 1. Czasy średniowieczne, Gdańsk 2006, ss. 536.

53 Tenże, Pierwsze państwo polskie, Kraków 1989, ss. 80 (wydane w ramach serii Krajowej Agencji Wydawniczej „Dzieje narodu i państwa polskiego”, t. 1, z. 2). Wznowienie tej pracy oraz cytowanej w przyp. 56 jej kontynuacji ukazało się po śmierci autora nakładem Wydawnictwa Nauka i Innowacje jako Pierwsze wieki monarchii piastowskiej, Poznań 2012, ss. 345.

54 Tenże, Mieszko II, król Polski (1025-1034). Czasy przełomu w dziejach państwa polskiego, Kraków 1992, ss. 213 (reedycja, Poznań 2008, ss. 236). Postać Mieszka II ukazał też G. Labuda w postaci popularnonaukowej biografii - Mieszko II, król Polski w czasach przełomu. 1025-1034, Poznań 1994, ss. 176.

55 Bibliografia prac Profesora Gerarda Labudy, s. 257-275.

56 G. Labuda, Korona i infuła. Od monarchii do poliarchii, Kraków 1996, ss. 72 (seria „Dzieje narodu i państwa polskiego", t. 1, z. 3).

57 Tenże, Święty Wojciech biskup - męczennik, patron Polski, Czech i Węgier, Wrocław 2000, ss. 337 (wznowienie Wrocław 2004, ss. 375). 
skutków ${ }^{58}$. Dodać trzeba, że materiał w niej zawarty był od ponad dwudziestu lat niemal gotowy i wydobyty z szuflady został w nieznacznym stopniu co do treści przerobiony, uzupełniona została bibliografia przedmiotu i przypisy. Ostatecznie w druku z wieloarkuszowego artykułu przybrał on formę pełnej monografii.

W ostatnich latach działalności naukowej G. Labuda stale powracał do tematyki związanej z pierwszymi wiekami monarchii Piastów. Swego rodzaju rozrachunkiem z tą częścią jego twórczości były wspominane tutaj Szkice historyczne X i XI wieku, wydane drukiem symbolicznie w 100. rocznicę ogłoszenia drukiem Szkiców historycznych $\mathrm{T}$. Wojciechowskiego ${ }^{59}$. Interesowaty go nie tylko kolejne rocznice (milenium męczeńskiej śmierci świętego Wojciecha, zjazdu gnieźnieńskiego czy Pięciu Braci Męczenników), ale także najnowsze odkrycia archeologiczne, które zmusiły mediewistów do stawiania nowych pytań o formowanie się państwowości polskiej pod egidą Piastów, o przebieg chrystianizacji, relacje z sąsiadami i wiele innych. Pisał i wiódł polemiki związane z postrzeganiem procesów państwowotwórczych i formowaniem organizacji kościelnej w Polsce do ostatnich dni. Pozostawił dzieło imponujące i trwałe, które stanowi przewodnik dla następnych pokoleń. Trzeba się z nim zmierzyć i twórczo je rozwijać.

Przez całe swe naukowe życie profesor G. Labuda pasje badawcze uzupełniał szeroko rozumianą działalnością organizacyjną na rzecz nauki w ramach rozmaitych instytucji lub realizował wielkie tematy i edycje. Wymagało to szczególnych, zważywszy skalę przedsięwzięć, często odmiennych umiejętności i podejścia. Działał nie tylko praktycznie - organizując zespoły badawcze, redakcje, skupiając wokół siebie uczonych rozmaitych profesji i przekonań z różnych pokoleń - ale również pisząc o problemach struktury, miejsca i roli nauki historycznej i nauki w szerokim rozumieniu na łamach rozmaitych periodyków (np. „Nauki Polskiej”).

Pierwszą z instytucji, na rzecz której pracował, był rodzimy Uniwersytet Poznański, na którym, jak wspomniano, zdobywał naukowe ostrogi i doświadczenie. Zaczynał od zaangażowania w kwestie porządkowania księgozbioru tuż po wojnie, następnie (od 1946 r.) kierował Katedrą Historii Słowiańszczyzny Zachodniej, a po zmianach organizacyjnych, od 1952 r., objął Katedrę Historii Polski, by w latach

58 Tenże, Święty Stanisław biskup krakowski - patron Polski. Śladami zabójstwa męczeństwa - kanonizacji, Poznań 2000, ss. 181.

59 Tenże, Szkice historyczne X i XI wieku, Poznań 2004. Równocześnie ukazało się kolejne wydanie pracy T. Wojciechowskiego Szkice historyczne jedynastego wieku, Poznań 2004 z przedmową G. Labudy (O piątym wydaniu Tadeusza Wojciechowskiego „Szkiców historycznych” słów kilka, s. 7-11). 
1957-1961 kierować Katedrą Historii Polski Feudalnej do XVIII wieku. Tutaj w roku akademickim 1950/1951 pełnił funkcję prodziekana Wydziału Humanistycznego, a w latach 1962-1965 był rektorem tej uczelni. To właśnie za jego czasów pojawiła się pierwszy raz koncepcja utworzenia dla UAM odrębnego kampusu, który miał być umiejscowiony, w myśl ówczesnych założeń, gdzieś na Marcelinie. Tę ideę $\mathrm{w}$ drugiej połowie lat siedemdziesiątych $\mathrm{XX}$ w. podjął jeden $\mathrm{z}$ jego następców na urzędzie rektorskim, zresztą uczeń, Benon Miśkiewicz (Kampus Morasko). Jego pomysłem było zacieśnienie współpracy między uczelniami Poznania, która od grudnia 1962 r. była realizowana w ramach Kolegium Rektorów Uczelni Poznańskich. Jego pierwszym przewodniczącym został G. Labuda ${ }^{60}$.

Przez wiele lat był cenionym dydaktykiem uniwersyteckim, po ustąpieniu z funkcji rektora w 1965 r. kierował Katedrą Historii Średniowiecznej (w 1969 r. przemianowaną na Zakład Historii Powszechnej i Polski do XV wieku). Jego odejście z UAM, a ściślej odmówienie mu przez tzw. komisję wiceministra Mistewicza prawa do zatrudnienia na dwóch etatach (UAM i PAN) i decyzja o zatrudnieniu wyłącznie w PAN, zostało wymuszone w 1970 r. (co miało charakter retorsji politycznej). Sytuację tę złagodzono przez formułę bezterminowego urlopu bezpłatnego, z którego nie został przed przejściem w stan spoczynku odwołany (mimo starań ówczesnego rektora Benona Miśkiewicza) ${ }^{61}$, ale aż do 1986 r. pełnił funkcję kierownika Zakładu Historii Średniowiecznej oraz otrzymywał nagrody rektorskie. Jak sam wspominał, status pełnoprawnego profesora Uniwersytetu im. Adama Mickiewicza przywrócił $\mathrm{mu}$ dopiero rektor Stefan Jurga ${ }^{62}$. Po wielu latach swoje doświadczenie i umiejętności dydaktyczne mógł oddać w 2000 r. na usługi Wyższej Szkoły Zarządzania i Bankowości w Poznaniu.

Od 1945 r. był członkiem Instytutu Zachodniego w Poznaniu, a w latach 1955-1961 jego wiceprezesem (do 1958) i prezesem, a jednocześnie autorem nowe-

60 O działaniach G. Labudy jako rektora UAM zob. T. Schramm, Gerard Labuda. 1 IX 1962 31 VIII 1965, [w:] Poczet rektorów Almae Matris Posnaniensis, red. T. Schramm, współpraca A. Marciniak, Poznań 2004, s. 199-208 (wyd. 2, red. T. Schramm, Poznań 2016, s. 201-211).

61 Zob. teczkę: Prof. dr hab. Gerard Labuda 1945-1987, Archiwum UAM, sygn. 744/718, a tutaj pisma: Rektora UAM prof. Czesława Łuczaka do ministra prof. Henryka Jabłońskiego (21 IX 1970); pismo prof. Gerarda Labudy do rektora UAM z 16 IX 1970 r., zaopiniowane przez dziekana prof. Jerzego Ochmańskiego (opinia odręczna z datą 18 IX 1970); pismo prof. G. Labudy do ministra Henryka Jabłońskiego z 19 IX 1970 r.

62 Teczka: Prof. dr hab. Gerard Labuda 1945-1987, Archiwum UAM, sygn. 744/718, a tutaj pisma: prof. G. Labudy do rektora UAM prof. Stefana Jurgi z 24 VIII 1999 r. i odpowiedź na nie $\mathrm{z}$ tego samego dnia. 
go programu naukowego tej instytucji po śmierci w 1955 r. jej twórcy, profesora Zygmunta Wojciechowskiego. Równocześnie, od 1948 r., był G. Labuda członkiem Poznańskiego Towarzystwa Przyjaciół Nauk, którego sekretarzem generalnym został w trudnym dla tej instytucji roku 1961 (pełnił tę funkcję do 1972 r.), przyczyniając się do jego uratowania wobec grożącej mu likwidacji. W latach 1972-1975 był prezesem tej placówki. W 1951 r., a więc tuż przed likwidacją, został członkiem korespondentem Polskiej Akademii Umiejętności, by w roku odnowienia tej instytucji (1989) przyczynić się znacząco do tego i zostać jej prezesem (do 1994 r., potem był prezesem honorowym). W $1964 \mathrm{r}$. został członkiem korespondentem, a w roku 1966 członkiem rzeczywistym Polskiej Akademii Nauk; w latach 1972-1980 pełnił funkcję prezesa jej Oddziału Poznańskiego, w latach zaś 1984-1989 wiceprezesa całej korporacji. Przez wiele lat kierował Zakładem Historii Pomorza (który kilka razy zmieniał nazwy) Instytutu Historii PAN, ale jego bliskie z nim związki wraz ze słynnymi środowymi zebraniami w ówczesnej siedzibie Zakładu przy ul. Zwierzynieckiej, to materiał na inną opowieść.

Profesor G. Labuda wielokrotnie podejmował się zadania organizowania zespołów badawczych, których celem było opracowanie tzw. węzłowych problemów badawczych wraz z publikacją materiałów. Nie uchylał się od trudu redagowania renomowanych czasopism - oczywiście redagowania w dosłownym tego słowa znaczeniu, a nie zasiadania w radach redakcyjnych. Owe wielkie problemy badawcze oraz tworzenie i redagowanie ważnych czasopism historycznych były powiązane z rozmaitymi działaniami instytucjonalnymi uczonego, zwłaszcza w ramach PAN i PTPN. Tutaj warto zwrócić uwagę tylko na kilka najważniejszych osiągnięć, które stanowiły niewątpliwy przełom w nauce historycznej. Szczególnym polem badawczym G. Labudy a jednocześnie osiągnięciem organizacyjnym były niewątpliwie dzieje Pomorza, oczywiście w ujęciu geograficznie rozległym (tzw. Wielkie Pomorze), z nałożeniem na dzieje zakonu krzyżackiego oraz dzieje Kaszubów i Kaszub. Te ostatnie studia należy bliżej wiązać z działalnością w ramach Polskiej Akademii Nauk i stworzeniem przy tej instytucji Zakładu Historii Pomorza, a także wydawaniem wielotomowej Historii Pomorza pod redakcją G. Labudy (od 1969). Łącznie zostały opublikowane cztery tomy, z czego ostatni pod redakcją Stanisława Salmonowicza, o całkowitej objętości przekraczającej 6000 stron. Tomy redagowane przez G. Labudę to złożone wewnętrznie dzieło zbiorowe, kompleksowo ukazujące dzieje Pomorza do połowy XIX stulecia na ponad 5000 stron druku. Przygotowaniem do tego pomnikowego przedsięwzięcia były trzytomowe, zredagowane przez uczonego, Szkice z dziejów Pomorza (wyd. w latach 1958-1961) oraz redagowane przezeń Dzieje Szczecina (t. 1-4, 1962-1998). W tym 
nurcie ukazały się też m.in.: Kaszubi i ich dzieje (2000), Zapiski kaszubskie, pomorskie i morskie. Wybór pism (2000) oraz Historia Kaszubów w dziejach Pomorza, t. I: Czasy średniowieczne (2006), a także liczne prace o dziejach Krzyżaków (np. wspomniana wyżej, przygotowana wspólnie z profesorem M. Biskupem synteza Dzieje Zakonu Krzyżackiego w Prusach czy studia o początkach Zakonu). Wytyczony przez niego nurt dociekań nad dziejami Brandenburgii i Prus, łączącymi się z historią Pomorza, zwieńczony wielotomową syntezą, realizowali już i kończyli jego uczniowie z profesorem Bogdanem Wachowiakiem na czele.

Drugim pomnikowym dziełem, którego jednym z inicjatorów i głównych wykonawców był profesor G. Labuda, jest Stownik starożytności stowiańskich. Ta ważna inicjatywa naukowa i edytorska wiąże się również z jego działalnością w instytucjonalnych ramach Polskiej Akademii Nauk (Komitet Słowianoznawstwa PAN i potem Instytut Słowianoznawstwa PAN). Począwszy od 1958 r., gdy ukazał się Stownik starożytności słowiańskich. Zeszyt dyskusyjny, G. Labuda współredagował to obszerne dzieło wielotomowe (początkowo wspólnie z Władysławem Kowalenką, Tadeuszem Lehrem-Spławińskim, potem skład redakcji się zmieniał), wydawane przez Ossolineum (t. I-VIII, 1961-1996). Do poszczególnych tomów, obejmujących dzieje wczesnej Słowiańszczyzny aż do końca XII stulecia, przygotował też wiele dziesiątków haseł.

Za jedno z najważniejszych osiągnięć organizacyjnych G. Labudy trzeba uznać wypracowanie koncepcji (wspólnie z profesorami: Aleksandrem Gieysztorem i Brygidą Kürbis) doskonałego periodyku poświęconego źródłom historycznym, źródłoznawstwu oraz naukom pomocniczym historii - „Studiów Źródłoznawczych” - i jego współredagowanie w latach 1957 (właściwie od 1955) - 1997 (t. I-XXXVI) z Gieysztorem i Kürbisówną, z czasem przy znaczącym wsparciu Ryszarda Walczaka (potem włączali się inni uczeni). Również i to przedsięwzięcie naukowe wyrastało z korzeni Polskiej Akademii Nauk, ale przez wiele dziesięcioleci integrowało środowiska historyków z rozmaitych polskich ośrodków nie tylko mediewistycznych. O dość zasmucających okolicznościach przeniesienia redakcji tego czasopisma do Warszawy nie czas i miejsce tu wspominać. Natomiast w ramach działalności w Poznańskim Towarzystwie Przyjaciół Nauk G. Labuda przez kilkadziesiąt lat współredagował i potem redagował ważny dla poznańskiego (i nie tylko) środowiska historycznego periodyk „Roczniki Historyczne”, którego założycielem był jeden z jego naukowych mentorów - profesor Kazimierz Tymieniecki (od t. XXIV z 1958 r. aż do roku 1986). Współpracował też przez wiele lat przy redagowaniu i wydawaniu wielotomowej Historii dyplomacji polskiej (t. I, 1982 r.). 
Wszechstronna działalność naukowa, dydaktyczna i organizacyjna przyniosła G. Labudzie wiele prestiżowych nagród, wyróżnień oraz odznaczeń. Najwyższą godność akademicką - doktorat honoris causa - przyznały mu uniwersytety polskie w: Krakowie, Warszawie, Toruniu, Gdańsku, Wrocławiu i Szczecinie. W 1996 r. Uniwersytet im. Adama Mickiewicza w Poznaniu uroczyście odnowił mu doktorat oraz przyznał medal Palmae Universitatis Studiorum Posnaniensis, a 12 XII 2006 r. odbyły się obchody 90. rocznicy jego urodzin. Otrzymał też prestiżowe nagrody naukowe: im. Herdera (Herder-Preis, Wiedeń, 1991 r.) oraz Fundacji Alfreda Jurzykowskiego (Alfred Jurzykowski Foundation, Nowy Jork, 1983 r.), wielokrotnie nagradzany był nagrodami państwowymi (w 2008 r. otrzymał nagrodę Ministra Nauki i Szkolnictwa Wyższego), jak również całą gamą odznaczeń państwowych, aż po Krzyż Wielki Orderu Odrodzenia Polski (1996). Nie tak dawno Kapituła Nagrody Lednickiego Orła Piastowskiego, w uznaniu zasług w badaniu początków dynastii Piastów i ukształtowanego przez nią państwa, przyznała profesorowi G. Labudzie jako pierwszemu statuetkę Lednickiego Orła (2008), a nieco tylko wcześniej (2006) Stały Komitet Mediewistów Polskich uhonorował go medalem Lux et laus. Za bogatą i wysokiej próby działalność naukową, niesłabnącą zresztą do ostatnich chwil życia, Prezydent Rzeczpospolitej Polskiej Bronisław Komorowski nadał mu pośmiertnie Order Orła Białego.

Profesor Gerard Labuda zmarł w godzinach rannych 1 X 2010 r., w dniu jakże dla uczonego symbolicznym - inauguracji roku akademickiego. 7 października pożegnała go społeczność akademicka Uniwersytetu im. Adama Mickiewicza w Poznaniu, a 8 października spoczął na cmentarzu w Luzinie koło Wejherowa, który jako syn ziemi kaszubskiej wybrał. Pracował do końca (zawsze twierdził, że praca jest dla człowieka najważniejsza), o czym świadczą pogłębiane w ostatnich latach badania nad swą „małą ojczyzną” - Kaszubami - czy też powrót do rozpoznania na nowo zarania dziejów państwowości polskiej w biografiach Mieszka I, Mieszka II, świętego Wojciecha bądź też w studiach krytyczno-analitycznych o świętym Stanisławie i wczesnych dziejach Kościoła polskiego. Nie zobaczył już swego ostatniego dzieła, opatrzonego obszernym, napisanym w 2009 r. posłowiem wznowienia tekstu o nowej systematyce i nowej interpretacji źródeł, przygotowanego przez Wydawnictwo Poznańskie ${ }^{63}$. Odszedł wielki uczony o bezsprzecznych zasługach dla polskiej nauki w ogólności, a historii szczególnie, którego dociekania przekładają się na ugruntowywanie w polskiej tradycji i pamięci zbiorowej obrazu przeszłości polskiego państwa,

63 G. Labuda, Próba nowej systematyki i nowej interpretacji źródet historycznych $z$ Postowiem, Poznań 2010, ss. 114. 
społeczeństwa i kształtującego się narodu. 10 XII 2010 r. w hołdzie profesorowi G. Labudzie Oddział Poznański Polskiej Akademii Nauk, Polska Akademia Umiejętności oraz Wydział Historyczny Uniwersytetu im. Adama Mickiewicza w Poznaniu zorganizowały konferencję „Początki państwa i Kościoła polskiego w badaniach Profesora Gerarda Labudy”. Poddano na niej oglądowi jeden z ważniejszych wątków badawczych podejmowanych przez tego uczonego - najwcześniejsze dzieje piastowskiej monarchii. Inne obszary jego naukowych zainteresowań czekają na pełniejsze podsumowanie. Częściowo zadanie to wypełniły konferencje - w Luzinie w pierwszą rocznicę śmierci profesora; w Krakowie (PAU) i w Wejherowie w stulecie jego urodzin oraz zorganizowana w maju 2016 r. sesja „Mediewiści rocznik 1916. W stulecie urodzin Aleksandra Gieysztora i Gerarda Labudy”. Teraz pora na biografię...

Nadesłany: 20 VI 2021

Nadesłany po poprawkach recenzyjnych: 11 VIII 2021

Zaakceptowany: 12 VIII 2021

Prof. dr hab. Józef Dobosz

Wydział Historii, Uniwersytet im. Adama Mickiewicza w Poznaniu

ul. Uniwersytetu Poznańskiego 7,

61-614 Poznań

e-mail: mediewal@amu.edu.pl

\section{Résumé}

\section{Gerard Labuda - a Sketch of a Portrait of a Scholar}

Gerard Labuda was born on 28 December 1916 in Nowa Huta, Kartuzy District. His scholarly achievements are difficult to embrace both in terms of the number of publications and the breadth of research horizons. He published about 2,000 various works (several dozen books, hundreds of articles, editions of sources, reviews and polemics, reports). The number of publications and their diverse subject matter, the excellence of his research methods and analytical finesse all arouse admiration. Not only did he specialise in broadly understood medieval studies (including medieval and universal history of Poland, the history of the early Slavdom and Germany, the history of the Polish Church, the history of the Teutonic Order, as well as source studies and auxiliary sciences of history), but he was also blazing the path of theoretical source science in Poland, undertook cross-sectional topics, studied the history of historiography and the development of historiographic methods throughout history and explored regional history. He did not shy away from popularizing history or taking 
up the subject of the broadly understood history of science. It is difficult to find an area in historiography in which Gerard Labuda did not move freely. If not a breakthrough in Polish historical science, each of the books and major dissertations was at least an important event that forced us to discuss and pose further questions and research problems.

Translated by Józef Dobosz

\section{Bibliografia/Bibliography}

Bibliografia prac Profesora Gerarda Labudy za lata 1935-2006, oprac. J. Strzelczyk, B. Wachowiak, J. Dobosz, H. Krzyżostaniak, [w: ] Naukowe dzieło Profesora Gerarda Labudy, red. J. Dobosz, Poznań 2006, s. 161-282

Biskup M., Labuda G., Dzieje Zakonu Krzyżackiego w Prusach. Gospodarka, społeczeństwo, państwo, ideologia, Gdańsk 1986

Borzyszkowski J., Gerard Labuda - Kaszuba z Poznania. Droga od „Historii Pomorza” do „Historii Kaszubów”, Przegląd Zachodni 2006, nr 1, s. 61-82

Borzyszkowski J., Wspomnienie o Wielkim Mistrzu... Profesorze Gerardzie Labudzie, [w:] tegoż, Moi Mistrzowie i Przyjaciele, Gdańsk 2015, s. 79-110

Dobosz J., Labuda Gerard, [w: Luminarze nauki Uniwersytetu Poznańskiego w latach 1919-2019, red. Z. Pilarczyk, Poznań 2019, s. 352-360

Dobosz J., Profesor Gerard Labuda (1916-2010), Wiadomości Historyczne 2011, nr 1, s. 51-53

Dobosz J., Profesor Gerard Labuda (28 grudnia 1916 - 1 października 2010), Lituano-Slavica Posnaniensia. Studia Historica 14 (2013), s. 31-35

Fopke T., Spuścizna Gerarda Labudy w muzeum wejherowskim. Budowa ksiąznicy i obchody Roku Gerarda Labudy - kalendarium dokonań, Acta Cassubiana 19 (2017), s. $106-126$

Historia dyplomacji polskiej (połowa X-XX w.), t. 1: Połowa X w. -1572, red. M. Biskup, Warszawa 1980

Jasiński T., Gerard Labuda (28 XII 1916 - 1 X 2010), Kwartalnik Historyczny 118 (2011), nr 2, s. 373-383

Kasprzyk G., Krośnicka M., Gerard Labuda. Żeglarz na oceanie nauki, Luzino 2011 Kłoczowski J., Gerard Labuda - historyk wczesnego chrześcijaństwa polskiego, [w: ] Naukowe dzieło Profesora Gerarda Labudy, red. J. Dobosz, Poznań 2006, s. 53-69 Kosman M., Gerard Labuda - człowiek i dzieło w 90. rocznicę urodzin, Przegląd Zachodni 2006, nr 1, s. 31-59 
Kosman M., Pożegnanie Profesora Gerarda Labudy (1916-2010), Zapiski Historyczne 75 (2010), z. 4, s. 157-163

Labuda G., Co historycy sądzq o Piastach jako twórcach państwa polskiego?, Kronika Wielkopolski 6 (1978), nr 1-4, s. 35-48

Labuda G., Daugerius episcopus, Onomastica 7 (1961), z. 1-2, s. 269-280

Labuda G., Dąbrówka czy Dobraw (k) a? Uzupetnienie do dyskusji o poprawne imię żony Mieszka I, Slavia Occidentalis 18 (1939/1947), s. 126-138

Labuda G., Droga biskupa praskiego Wojciecha do Prus, Zapiski Historyczne 34 (1969), z. 3, s. 9-28.

Labuda G., Fragmenty dziejów Stowiańszczyzny zachodniej, t. 1-3, Poznań 1960-1975 Labuda G., Historia Kaszubów w dziejach Pomorza, t. 1: Czasy średniowieczne, Gdańsk 2006

Labuda G., Ibrahim ibn Jakub. Najstarsza relacja o Polsce w nowym wydaniu, Roczniki Historyczne 16 (1947), s. 100-183

Labuda G., Jakimi drogami przyszło do Polski chrześcijaństwo?, Nasza Przeszłość 69 (1988), s. 39-82

Labuda G., „Jestem Kaszuba w Poznaniu”. Rozmowa z Beata Maciejewska, Gazeta Dolnośląska, dodatek do Gazety Wyborczej, 15.09.1999

Labuda G., Korona i infuła. Od monarchii do poliarchii, Kraków 1996

Labuda G., Kraków biskupi przed 1000 r. Przyczynek do dyskusji nad dziejami misji metodiańskiej w Polsce, Studia Historyczne 27 (1984), z. 3, s. 371-412

Labuda G., Król Bolesław „qui constituit episcopatus per Poloniam”, Studia Źródłoznawcze 30 (1987), s. 51-57

Labuda G., List papieża Paschalisa II do niewiadomego arcybiskupa polskiego z poczatku XII w. Przyczynek do dyskusji nad faktum biskupa krakowskiego Stanisława, Śląski Kwartalnik Historyczny „Sobótka” 26 (1971), nr 4, s. 415-434

Labuda G., Magdeburg i Poznań (Założenie arcybiskupstwa magdeburskiego i biskupstwa poznańskiego na tle wschodniej polityki misyjnej Ottona Wielkiego), Roczniki Historyczne 14 (1938), z. 2, s. 185-238

Labuda G., Mieszko II, król Polski (1025-1034). Czasy przełomu w dziejach państwa polskiego, Kraków 1992

Labuda G., Mieszko II, król Polski w czasach przełomu. 1025-1034, Poznań 1994

Labuda G., O najstarszej organizacji Kościoła w Polsce, Przegląd Powszechny 1984, nr 6, s. 373-396

Labuda G., O piątym wydaniu Tadeusza Wojciechowskiego „Szkiców historycznych” 
słów kilka, [w:] T. Wojciechowski, Szkice historyczne jedenastego wieku, Poznań 2004, s. 7-11

Labuda G., O rzekomej utracie Krakowa przez Czechów w roku 999, Slavia Occidentalis 20 (1960), z. 2, s. 79-93

Labuda G., Piastowie twórcami państwa polskiego, [w:] Piastowie w dziejach Polski. Zbiór artykutów $z$ okazji trzechsetnej rocznicy wygaśnięcia dynastii Piastów, red. R. Heck, Wrocław 1975, s. 10-48

Labuda G., Pierwsze państwo polskie, Kraków 1989

Labuda G., Początki diecezjalnej organizacji kościelnej na Pomorzu i na Kujawach w XI i XII wieku, Zapiski Historyczne 33 (1968), z. 3, s. 19-60

Labuda G., Poczatki klasztoru w świetle źródet pisanych, [w:] Materiaty sprawozdawcze $z$ badań Zespołu Pobenedyktyńskiego w Mogilnie, red. K. Nowiński, z. 1, Warszawa 1978, s. 21-60

Labuda G., Początki państwa polskiego w historiografii polskiej i niemieckiej, [w:] Stosunki polsko-niemieckie w historiografii, cz. 1: Studia z dziejów historiografii polskiej i niemieckiej, red. J. Krasuski, G. Labuda, A.W. Walczak, Poznań 1974, s. 150-217

Labuda G., Polska a Skandynawia w IX-X wieku, [w: ] Początki państwa polskiego. Księga tysiąclecia, t. 1, Poznań 1962, s. 299-317

Labuda G., Polska granica zachodnia. Tysiąc lat dziejów politycznych, Poznań 1971

Labuda G., Polska w pieśni o Rolandzie, Roczniki Historyczne 22 (1955/1956), s. $35-59$

Labuda G., Polskie wczesne średniowiecze w historiografii lat 1937-1987, Kwartalnik Historyczny 94 (1987), nr 1, s. 23-65

Labuda G., Polsko-niemieckie rozmowy o przeszłości. Zbiór rozpraw i artykutów, Poznań 1996

Labuda G., Próba nowej systematyki i nowej interpretacji źródeł historycznych z Posłowiem, Poznań 2010

Labuda G., Rozważania nad teoria i historią kultury i cywilizacji. Wybór studiów i rozpraw, Poznań 2008

Labuda G., Stowiańszczyzna pierwotna. Wybór tekstów, Warszawa 1954

Labuda G., Studia krytyczne o początkach Zakonu Krzyżackiego w Prusach i na Pomorzu. Pisma wybrane, Poznań 2007

Labuda G., Studia nad początkami państwa polskiego, Poznań 1946

Labuda G., Studia nad poczatcami państwa polskiego, t. 1, Poznań 1987

Labuda G., Studia nad poczatkami państwa polskiego, t. 2, Poznań 1988 
Labuda G., Studia nad początkami państwa polskiego, t. 3, Wodzisław Śląski 2012

Labuda G., Szkice historyczne X-XI wieku. Z dziejów organizacji Kościoła w Polsce we wczesnym średniowieczu, Poznań 2004

Labuda G., Święty Stanisław biskup krakowski - patron Polski. Śladami zabójstwa męczeństwa - kanonizacji, Poznań 2000

Labuda G., Święty Wojciech biskup - męczennik, patron Polski, Czech i Węgier, Wrocław 2000

Labuda G., Św. Wojciech w literaturze i legendzie średniowiecznej, [w:] Święty Wojciech 997-1947, red. Z. Bernacki i in., Gniezno 1947, s. 89-112

Labuda G., Utrata Moraw przez państwo polskie w XI wieku, [w:] Studia z dziejów polskich i czechosłowackich, red. E. Maleczyńska, K. Maleczyński, t. 1, Wrocław 1960, s. 9-124

Labuda G., W 75 rocznicę ukazania się „Szkiców historycznych” Tadeusza Wojciechowskiego, Kwartalnik Historyczny 88 (1981), nr 2, s. 323-351

Labuda G., Wpływ powstania państwa polskiego na rozwój dziejowy Pomorza, [w: ] Początki państwa polskiego. Księga tysiąclecia, t. 2, Poznań 1962, s. s. 269-279

Labuda G., Zagadka drugiej metropolii w Polsce za czasów Bolestawa Chrobrego, Nasza Przeszłość 62 (1984), s. 7-25

Labuda G., Zagadnienie suwerenności Polski wczesnofeudalnej w X-XII wieku, Kwartalnik Historyczny 67 (1960), nr 4, s. 1035-1068

Labuda G., Zaginiona kronika z pierwszej połowy XIII wieku w Rocznikach Królestwa Polskiego Jana Długosza. Próba rekonstrukcji, Poznań 1983

Labuda G., Zapiski kaszubskie, pomorskie i morskie, Gdańsk 2000

Labuda G., Zapiski rocznikarskie w żywotach Świętego Stanisława Wincentego z Kielczy, Roczniki Humanistyczne 34 (1986), z. 2, s. 319-332

Labuda G., Zatargi z Czechami i Pomorzanami w pierwszym okresie rządów Bolestawa Śmiałego (1058-1073), Zap. Hist. 50 (1985), z. 3, s. 33-50

Labuda G., Z dyskusji nad poczatkami klasztoru benedyktyńskiego w Tyńcu. Fundatorzy i pierwsi opaci, [w:] Symbolae historiae artium. Studia z historii sztuki Lechowi Kalinowskiemu dedykowane, Warszawa 1986, s. 93-109

Labuda G., Znaczenie prawno-polityczne dokumentu Dagome iudex, Nasza Przeszłość 4 (1948), s. 33-60

Labuda G., Źródła objaśniające początki państwa polskiego. Projekt wydawnictwa, Kwartalnik Historyczny 58 (1951), nr 1-2, s. 112-122

Labuda G., Źródła, sagi i legendy do najdawniejszych dziejów Polski, Warszawa 1960 
Michałowski R., Poczatki państwa polskiego w badaniach naukowych Gerarda Labudy, [w: ] Naukowe dzieto Profesora Gerarda Labudy, red. J. Dobosz, Poznań 2006, s. $71-86$

Naukowe dzieto Profesora Gerarda Labudy, red. J. Dobosz, Poznań 2006

Obracht-Prądzyński C., Gerard Labuda - z Kaszub do historii Kaszubów, Nauka 2016, nr 3, s. 171-189

Olszewski H., Gerard Labuda, [w:] tegoż, Ludzie Uniwersytetu w mojej pamięci, Poznań 2015, s. 243-248

Poczattki państwa i Kościoła polskiego w badaniach naukowych Profesora Gerarda Labudy, red. J. Strzelczyk i in., Poznań 2011

Profesor Gerard Labuda. Dokonania, idee, inspiracje, Acta Cassubiana 19 (2017), s. $7-126$

Pro memoria Gerard Labuda (1916-2010), oprac. i wstęp J. Borzyszkowski, GdańskWejherowo 2011

Schramm T., Gerard Labuda. 1 IX 1962 - 31 VIII 1965, [w:] Poczet rektorów Almae Matris Posnaniensis, red. T. Schramm, współpraca A. Marciniak, Poznań 2004, s. 199-208 (wyd. 2, red. T. Schramm, Poznań 2016, s. 201-211)

Schramm T., Gerard Labuda. Zarys biografii, [w: ] Naukowe dzieło Profesora Gerarda Labudy, red. J. Dobosz, Poznań 2006, s. 9-19

Schramm T., Gerard Labuda. Zarys biografii, [w: ] Pro memoria Gerard Labuda (1916-2010), oprac. i wstęp J. Borzyszkowski, Gdańsk-Wejherowo 2011, s. $15-28$

Stowiańszczyzna starożytna i wczesnośredniowieczna. Antologia tekstów źródłowych, Poznań 1999, ss. 275.

Strzelczyk J., Gerard Labuda 1916-2010, Roczniki Historyczne 76 (2010), s. 9-26 Strzelczyk J., Żywot niezwykly. W pięciolecie śmierci profesora Gerarda Labudy, PAUza Akademicka. Tygodnik Polskiej Akademii Umiejętności 8 (2015), nr 315 z 19 listopada, s. 1-3

Teksty źródłowe do ćwiczeń z historii Polski epoki feudalizmu (do połowy XIV wieku), oprac. G. Labuda, B. Miśkiewicz, z. 1-4, Poznań 1961-1963

Wybór źródet do historii Polski średniowiecznej (do połowy XV), t. 1-3, Poznań 19661970

Źródła skandynawskie i anglosaskie do dziejów Stowiańszczyzny, wyd. G. Labuda, Warszawa 1961 